\title{
Do Accounting Numbers Have Any Relation with Stock Prices? A Case of Public and Private Sector Banks of India
}

\author{
Meena Bhatia $^{{ }^{*}}$, Mwila Joseph Mulenga ${ }^{2}$ \\ ${ }^{1}$ Department of Accounting and Finance, Birla Institute of Management Technology, Greater Noida, India \\ ${ }^{2}$ Institute of Finance and Management (IFM), Dar es Salaam, Tanzania \\ Email: *meena.bhatia@bimtech.ac.in, mwilamulenga2011@gmail.com
}

How to cite this paper: Bhatia, M. and Mulenga, M.J. (2019) Do Accounting Numbers Have Any Relation with Stock Prices? A Case of Public and Private Sector Banks of India. Theoretical Economics Letters, 9, 1682-1698.

https://doi.org/10.4236/tel.2019.95107

Received: May 10, 2019

Accepted: June 27, 2019

Published: June 30, 2019

Copyright ( 2019 by author(s) and Scientific Research Publishing Inc. This work is licensed under the Creative Commons Attribution International License (CC BY 4.0).

http://creativecommons.org/licenses/by/4.0/

(c) (i) Open Access

\begin{abstract}
Capital market research examines the ability of accounting numbers to influence the stock prices thus stock returns. This paper attempts to study the association between the accounting variables and stock price for banking sector in India and also to explore whether same variables influence the stock price of private and public sector banks in India. Nine accounting variables for the period of ten years have been studied for BSE listed banks. The study used panel least regression analysis by incorporating Fixed effect model (FEM) and Random effect model (REM), where nine set of accounting variables regressed against market share price of private and public sector banks for a period of 10 years from 2005 to 2014. The empirical findings revealed that, out of nine independent variables used; the earnings per share, book value per share, assets turnover and current ratio were significant in private sector banks and earnings per share, book value per share, return on equity and net non-performing assets ratio were significant in public sector banks. Overall empirical findings reported that the fundamental accounting variables in public sector banks are more relevant than that of private sector banks and this supports the hypothesis of the study. This is against the notion raised in 90 s that accounting information has become less value relevant.
\end{abstract}

\section{Keywords}

Accounting Numbers, Share Price, Bombay Stock Exchange, Private Sector Banks, Public Sector Banks, Value Relevance, India

\section{Introduction}

The financial reporting system has been evolving in the world; detailed and de- 
manding accounting principles and standards are augmented by extensive disclosure requirements. When FASB and IASB set standards for financial reporting, they make many judgments and they formulate standards by keeping in mind the objective of financial reporting. The objective of financial reporting is "to provide information that is useful to present and potential investors and creditors and others in making investment, credit and similar resource allocation decisions". For accounting information to be useful for decision making it is essential that it is relevant for decision making. It should also truly capture the economic substance of the transactions, events, or circumstances it describes and the information needs to be complete, neutral and free from material errors [1]. $I A S B$ (2001, p. 26) considers financial statement information to be relevant when it has the ability of influencing user's economic decision by helping them to evaluate past, present and future events and correcting their past evaluation.

Research that examines the relationship between financial statement information and capital markets is referred to as capital markets research; it originated from seminal work of [2]. The voluminous published research in this area is an indication of the demand for capital markets research. As per [3] during 1980s and 1990s the source of the demand for capital markets research was from five areas i.e. methodological capital markets research, evaluation of alternative accounting performance measures, tests of market efficiency, valuation and fundamental analysis and value relevance.

Value relevance studies are designed to assess whether particular accounting amounts reflect information that is used by investors in valuing equity [4]. There are four categories of Value relevance studies identified by [5], 1) fundamental view, as per this the stock price changes as the accounting information reflected in financial statements change; 2) prediction view accord relevance to financial information as it helps in predicting the future accounting variables; 3 ) information view; here the premise is that the accounting information is value relevant if it is used by investors for setting prices; 4) measurement view which does not assume that investors use the information; it works on the notion that if an accounting variable has a relation with market price; then it is believed that it is capturing information that is used by the investors.

Close to half of the annual report comprises of financial statements and related information, for an investor it is essential to identify the relevant information to assess the business performance and position and to evaluate the ability of the business to generate future earnings [1]. Accounting information is used as a major means of communication between listed companies and existing shareholders [6]. To increase the level of transparency the Standard setters and market regulators carry out the improvements in the quality of accounting information presented in financial statements [7]. Value relevance research is considered to be important also because it operationalize key dimensions of the FASB's theory to assess relevance and reliability of accounting amounts and that is the motivation behind this study. Several studies [8]-[19] have empirically examined value relevance of accounting information in Indian context with 
emphasis on the accounting information reported in the balance sheet, income statement and cash flow statement, few studies [7] [10] [20] gave more emphasizes on accounting information reported in the cash flow statement. None of these studies focused on value relevance comparison within the banking sector i.e. public and private sector banks in India, this study fills this gap in literature by doing the investigation in this direction. More so banking sector does play a vital role in the economy [21], forms the core of the money market [22] and is the main participant of the financial system [23].

For conducting the analysis so as to compare the value relevance accounting information between private and public sector banks, the study used the list of Indian banks listed in Indian stock market; and to test the relative association study used a set of nine independent accounting variables. Many of these accounting variables are unique to banking sector and users of financial statements use them for evaluating past and future financial performance and position of the banks. This study not only adds to the value relevance literature by comparing value relevance of accounting information between Indian private and public sector banks but also has considered additional variables not considered by other studies and as per the findings few of the additional variables are significant too.

The findings of our study indicated that, out of nine independent variables used, four variables are significant of which two are common for public and private sector banks. Overall empirical findings reported that accounting information in public sector banks is more relevant than that of private sector banks and this supports the hypothesis of the study that there is significant difference in the value relevance of accounting information between public sector banks and private sector banks.

The structure of this paper is organized as follows. The review of empirical literature is covered in Section 2, methodology used is discussed in Section 3. Section 4 focuses on empirical findings and analysis, conclusion and recommendation of the study are reflected in Section 5, and Section 6 is for limitation and suggestion for future research.

\section{Review of Empirical Literature}

The literature examining the association between stock price and accounting information extends back over 50 years [2] [24] [25] the first study which used the term "value relevance" to describe this association is [26]. The work done by [2] [25] endorsed the information approach of value relevance; this approach focused on usefulness of accounting information for investors and it did not paid much attention to specific structure of the relation between market value and accounting information

The theoretical framework of equity valuation originated from the Ohlson model [27], as per this model value of the firm can be expressed as a linear function of earnings, book value and other relevant information; this framework was based on the measurement approach. Large proportion of the studies reviewed in this paper use the measurement approach of value relevance. The research de- 
sign varies among different studies, depending on the matter of the investigation. Three categories of research design have been used in the studies [28], namely relative association, incremental association and marginal information content studies. The relative association studies [29] [30] associate the stock market values with alternative accounting measures, these studies use $\mathrm{R}^{2}$ measure of regression to arrive at conclusions. Incremental association studies [31] examine whether a particular variable can explain stock market value given other accounting variables; the variable is considered to be relevant if the regression coefficient is significantly different from zero. Marginal information content studies [26] are typically event studies which enquires whether an accounting variable adds to the information available to the stakeholders. Most of the value-relevance studies perform association studies (relative and/or incremental).

[30] enquired about association of earnings with stock prices for German corporations and findings suggested that there is significant association between the two. This study used $\mathrm{R}^{2}$ as a measure of value relevance. Study by [29] examined the association between comprehensive income and net income with stock prices and concluded that the association between net income and stock prices is stronger than the association between comprehensive income and stock prices. [32] compared value relevance of accounting information of two countries namely Czech Republic and Sweden. The value relevance of accounting information in Czech Republic reported to be low than in Sweden. In addition, [33] examine value relevance of earnings under three accounting regimes including German GAAP, US GAAP and IAS. The value relevance of earnings reported to high in US GAAP and IAS, than in German GAAP. Also, [34] investigated value relevance of accounting information by considering a sample of six countries including Indonesia, Malaysia, Philippine, South Korea, Taiwan and Thailand. In all countries accounting information used reported to be statistically significant.

An incremental association study by [35] examined the difference between fair value estimates and the historical cost of banks investment securities. The results show that fair value estimates of investments securities provide a significant explanatory power compared to historical costs. As per [36] banks valuation of equity is impacted by unique bank variables and economic variables and asset quality is of high importance. For banking sector studies have focused on linking disclosures norms with that stock returns [35] [37] [38]. As per study based on banks in Sri-Lanka [39] investors based their investment decisions on the basis of aggregated accounting information in financial statements and Earnings per share and Return on equity are significantly related with the share price. Another study on banks in Nigeria [40] concluded that the earnings and change in earnings are value relevant.

In Indian context few value relevance studies have been conducted. [7] is amongst the first few Indian study that explored value relevance; though the data set has been small the findings were that the accounting information provided in 
cash flow statement has insignificant impact on share price. [13] examined value relevance by using price model and the findings were that earnings per share and book value per share significantly influence stock prices. As per [11] dividend per share is more relevant in private sector and public sector companies while book value per share is relevant in private sector only and earnings per share is insignificant in public sector companies. [10] examined value relevance of accounting information between IT sector and Steel sector. The study used six set of accounting variables, and out of six variables used only returns on net worth, cash flow from operation to total assets and debt to equity ratio are positive and statistically significant in IT sector and investment to total assets and debt to equity are positive and statistically significant in steel sector. As per study by [12] return on net worth is significant for equity investors. Others studies based in India [8] [12] [20] concluded that accounting information reported in cash flow statement is not relevant. Study on FMCG sector of India by [14] concluded that investment expenditure and dividend influence the stock price significantly. [19] carried out value relevance study of reported financials of NSE listed companies and found that accounting information is relevant in explaining stock prices and stock returns, the variables considered by the study was EPS and BVPS and this study did not consider banking sector.

As evident from the literature no empirical study in Indian context compared value relevance of accounting information between private and public sector banks, therefore this present study aimed to fill the gap in literature.

\section{Research Methodology}

\subsection{Research Questions}

1) Do accounting numbers have any relation with stock price of private and public sector banks of India?

2) Is there any significant difference in the relative association of accounting information and stock price between private and public sector banks?

\subsection{Research Design}

\subsubsection{Sample and Data}

The data required for the study is sourced from three sources, 1) the annual financial reports, 2) prowess database maintained by the Center for Monitoring the Indian Economy (CMIE) and 3) Reserve Bank of India official website. There are 40 banks listed on Bombay Stock Exchange and/or National Stock Exchange, we had to drop three banks as the relevant information was missing for these banks. The constituents of the study are given in Table 1(a) and Table 1 (b).

\section{Model Specification}

To test the relationship, market shares prices regressed against nine set of accounting variables. Description of the variables is given in Table 2. The empirical model to be estimated is presented below. 
Table 1. (a): Constituents of the study; (b): Constituents of the study.

(a)

\begin{tabular}{|c|c|c|c|c|c|c|}
\hline No. & Public & secto & banks & No. & Private secto & banks \\
\hline 1 & Andhra Bank & 14 & Punjab National Bank & 1 & Axis Bank & 14 Yes Bank \\
\hline 2 & Allahabad & 15. & Syndicate Bank & 2 & City Union Bank & \\
\hline 3 & Bank of Baroda & 16. & State Bank of India & 3 & Dhanlaxmi Bank & \\
\hline 4 & Bank of India & 17. & State Bank of Mysore & 4 & DCB & \\
\hline 5 & Bank of Maharashtra & 18. & State Bank of Bikaner & 5 & Federal Bank & \\
\hline 6 & Canara Bank & 19 & $\begin{array}{l}\text { State bank of } \\
\text { Travancore }\end{array}$ & 6 & HDFC Bank & \\
\hline 7 & Corporation Bank & 20. & United Bank of India & 7 & ICICI Bank & \\
\hline 8 & Central Bank of India & 21. & Union Bank of India & 8 & Indusind Bank & \\
\hline 9 & Dena Bank & 22. & UCO Bank & 9 & Jammu and Kashmir & \\
\hline 10 & IDBI Bank & 23. & Vijaya Bank & 10 & Karnataka Bank & \\
\hline 11 & Indian Overseas & & & 11 & Kotak Mahindra & \\
\hline 12 & Indian Bank & & & 12 & Lakshmi Vilas Bank & \\
\hline 13 & $\begin{array}{l}\text { Oriental Bank of } \\
\text { Commerce }\end{array}$ & & & 13 & South Indian bank & \\
\hline
\end{tabular}

(b)

\begin{tabular}{ccc}
\hline S/No. & Type of Bank & Number \\
\hline 1 & Private Sector Bank & 14 \\
2 & Public Sector Bank & 23 \\
& Total & 37 \\
\hline
\end{tabular}

$$
\begin{aligned}
\operatorname{MSP}_{i t}= & \alpha_{0}+\beta_{1} \mathrm{EPS}_{i t}+\beta_{2} \mathrm{BVPS}_{i t}+\beta_{3} \mathrm{ROE}_{i t}+\beta_{4} A T R_{i t}+\beta_{5} \mathrm{CR}_{i t} \\
& +\beta_{6} \mathrm{NIM}_{i t}+\beta_{7} \mathrm{CAR}_{i t}+\beta_{8} N P A_{i t}+\beta_{9} C A S A_{i t}+\varepsilon_{i}
\end{aligned}
$$

\subsubsection{Description of Independent Variables Used in the Study}

1) Earnings per share: Earnings per share is the portion of a company's profit allocated to each outstanding share of common stock and used as an indicator of firms' profitability [19]. This is considered to be the most important accounting variable impacting the stock market; thus is used in many value relevance studies and found to be significant in varied stock market across the globe.

2) Book value per share: Book value per share is considered as a very important accounting information in measuring amount of assets the company has on behalf of each equity share [19]. Company is considered to have good performance if its book value is high [41].

3) Return on equity: It is measure of profitability and is an indicator of firms' efficiency and focused on measuring amount of profit generated by the company using amount of money invested by a shareholder in the company [10].

4) Assets turnover ratio: Assets turnover ratio used as independent variable in this study, the ratio defined as part of efficiency ratio aimed in measuring ability 
Table 2. Description of dependent and independent variables used.

\begin{tabular}{|c|c|c|c|}
\hline Name & Nature & Formula & Description \\
\hline$M S P_{i t}$ & Dependent variable & Closing market price & $\begin{array}{l}\text { Market share price of firm } i \text { at time } t \\
\text { represented by closing price at end of } \\
\text { financial year }\end{array}$ \\
\hline$A$ & Independent & $\begin{array}{l}\text { Captures the influence of variables that have been excluded } \\
\text { on the dependent variable }\end{array}$ & $\mathrm{d}$ from the model but exercise some influence \\
\hline$E P S_{i t}$ & Independent variable & $\frac{\text { Earnings attributable to ordinary shareholders }}{\text { Total amount of outstanding ordinary shares }}$ & Earnings per share of firm $i$ at time $t$ \\
\hline$B V P S_{i t}$ & Independent variable & $\frac{\text { Equity share capital }+ \text { shareholders reserves }}{\text { Total number of outstanding ordinary shares }}$ & Book value per share of firm $i$ at time $t$ \\
\hline$R O E_{i t}$ & Independent variable & Net income/Shareholder's equity & Return on equity of firm $i$ at time $t$ \\
\hline$A T R_{i t}$ & Independent variable & Total amount of sales or turnover/Total amount of assets & Assets turnover ratio of firm $i$ at time $t$ \\
\hline$C R_{i t}$ & Independent variable & Current assets/Current liabilities & Current ratio of firm $i$ at time $t$ \\
\hline$N I M_{i t}$ & Independent variable & Net interest income/Average interest earnings assets & Net interest margin of firm $i$ at time $t$ \\
\hline$C A R_{i t}$ & Independent variable & Tier I capital + Tier II capital/Risk weighted assets & Capital adequacy ratio of firm $i$ at time $t$ \\
\hline Net $N P A_{i t}$ & Independent variable & Net non-performing assets/Loans given & Net Non Performing Assets \\
\hline$C A S A_{i t}$ & Independent variable & $\frac{\text { Deposit in Current account and Savings account }}{\text { Total amount of deposits }}$ & $\begin{array}{l}\text { Current account and Savings account } \\
\text { deposits ratio of firm } i \text { at time } t\end{array}$ \\
\hline $\mathrm{T}$ & Time & Represents the number of years covered for this study & $\begin{array}{l}2005, \cdots, 2014, \text { corresponding to the years } \\
2006-2014\end{array}$ \\
\hline
\end{tabular}

of the company in utilizing its assets for the purpose of generating company's sales. According to [42] efficient utilization firm's assets and proper generation of sales is found when the ratio reported to be high, very few studies examined value relevance of this ratio for equity valuation.

5) Current ratio: Current ratio is a part of liquidity ratio which is mostly used in measuring ability of the companies to meet is short term obligation [43]. The ratio used as independent variable in this study, consistent with other researchers including [10] [42] [44].

6) Net interest margin: Business of banks is primarily concerned with expected returns [21]. The net interest margin (NIM) considered as a very important ratio in banking sector and is in measuring efficient utilization of bank's funds in generating income from investment and credit operations [45].

7) Capital adequacy ratio: The capital adequacy ratio $(C A R)$ also known as Capital to risk weighted assets ratio $(C R A R)$ used in measuring amount of bank's capital in relation to the amount of its credit exposures. The ratio expressed as a percentage of bank's capital to its risk weighted credit exposures and used as a measure of bank's financial strength and stability. Banks with high capital adequacy ratio are considered to be safe, in case its loans are not going well they can make up for it from its net worth.

8) Net non-performing assets ratio: Non-performing assets $(N P A)$ considered as the major concern for the Indian banks because the ratio used as indicator of the financial health of the banking sector and credit risk [46]. High level of 
$N P A s$ indicates that there are large number of credit defaulters which impacts bank's profit ability adversely, and also impacts the value of the assets and net-worth and this can result in bank failures.

9) Current account and saving account ratio: It is used to show the amount of deposits a bank has in form of current account and savings account of the total amount of deposits. For the banks with higher ratio of current deposits and savings deposits, it is considered to be a good signal as funds available through these two deposits have very low cost. As far as our knowledge none of the previous studies considered this variable, but the stock market analysts have always accorded high value to this ratio of banking industry. Therefore we have included it in our study.

\subsubsection{Research Models}

This study uses Fixed effect model (FEM) and Random effect model (REM) to conduct the analysis, as it considers the effect of systematic differences between the firms as compared with OLS which assumes that model parameters are constant across all firms [47]. These two panel data regressions models are applied to get accurate estimates and also to control unobserved heterogeneity and the problem of endogeneity [48]. In order to choose the appropriate model between FEM and REM based upon the consistency of estimated results [49], specification test was also conducted. The test normally assumes the null hypothesis, that there is no correlation between error term and explanatory variables and hence, REM should be used. Alternatively FEM is appropriate assuming there is correlation between error term and explanatory variables. Decision rule is under 5\% significant level if Hausman test statistic has probability less than 0.05 then it is possible to reject null hypothesis meaning FEM is appropriate. The results of the Hausman test in our study reject (accept) the null hypothesis at 5 per cent significance level, thereby supporting the use of FEM (REM) for analysis in private (public) sector banks. The results are of the view that fixed (random) effect model is the most appropriate and consistent model for analysis in private (public) sector banks.

\section{Results and Analysis}

\subsection{Descriptive Statistics}

Table 3 presents the descriptive statistics; it can be observed that public sector banks reported the highest mean value of $M S P$ with standard deviation followed by $B V P S$. The mean value of $M S P$ as reports by public sector banks is 546.4 with standard deviation of 1247.1 and 416.4 reported as the mean value of $B V P S$ with standard deviation of 678.2. While the lowest mean value found in $C R$ under both sectors. The corresponding estimates for both sector also reveal that, indicated that the minimum value of 0.05 and 0.01 perceived in $A T R$ and $C R$ in public sector banks while in private banks stock the minimum value of -25.23 and -66 perceived in $E P S$ and $R O E$ respectively. 
Table 3. Descriptive statistics of the dependent and independent variables.

\begin{tabular}{cccccccccccc}
\hline Variables & MSP & EPS & BVPS & ROE & ATR & CR & NIM & CAR & NPA & CASA \\
\hline & & & \multicolumn{7}{c}{ Public Sector Banks } & & \\
Mean & 546.4 & 68.21 & 416.4 & 15.50 & 0.10 & 0.03 & 2.64 & 12.55 & 1.39 & 32.82 \\
Median & 144.4 & 23.77 & 153.2 & 15.61 & 0.09 & 0.03 & 2.66 & 12.52 & 1.19 & 32.35 \\
Std. Deviation & 1247.1 & 129.85 & 678.2 & 6.42 & 0.09 & 0.03 & 0.61 & 1.21 & 0.92 & 6.70 \\
Minimum & 22.2 & -28.68 & 0.00 & -31.32 & 0.05 & 0.01 & 0.23 & 9.21 & 0.15 & 14.59 \\
Maximum & 9675.6 & 885.71 & 3827.3 & 29.85 & 0.09 & 0.45 & 3.98 & 18.16 & 7.18 & 49.82 \\
\hline & & & & Private Sector Banks & & & & \\
\hline Mean & 368.6 & 27.44 & 192.7 & 11.68 & 0.10 & 0.04 & 2.91 & 14.04 & 1.23 & 27.75 \\
Median & 188.7 & 16.95 & 116.5 & 14.11 & 0.10 & 0.03 & 2.81 & 13.47 & 0.83 & 25.05 \\
Std. Deviation & 389.2 & 38.89 & 209.2 & 11.84 & 0.01 & 0.03 & 0.81 & 2.72 & 1.55 & 11.00 \\
Minimum & 21.4 & -25.23 & 10.9 & -66.51 & 0.04 & 0.01 & 1.08 & 8.67 & 0.00 & 1.38 \\
Maximum & 2034.0 & 243.92 & 1180.3 & 32.30 & 0.14 & 0.15 & 5.62 & 22.46 & 14.11 & 60.65 \\
\hline
\end{tabular}

\subsection{Correlation Matrix Analysis and Multi-Collinearity}

The relationship between accounting variables and market share prices was measured by using the Pearson's Correlation analysis. As indicated in Table 4, the highest and strong positive correlation of 0.932 is reported between MSP and $E P S$ followed by $B V P S$ (0.911) in public sector banks; this is inconsistent with [50]. Other accounting variables like $R O E, A T R, N I M$ and $C A S A$ showing low positive correlation with market share prices whereas $C R, C A R$ and NPA showing low negative correlation with market share price.

In private sector, MPS is positively correlated with all accounting variable except $N P A$ have negative correlation with $M S P$. The highest and strong positive correlation of 0.699 is reported between $C A S A$ and MPS followed by BVPS (0.631). The results from Pearson's correlation coefficient in Table 3 also indicated that none of variables except EPS and BVPS have correlation above 0.9 under both sectors. Highpair wise correlation is not a foolproof guide to collinearity due to interaction between several independent variables [51]. In addition, Variance Inflation Factor (VIF) was performed to check if the effect of multicollinearity between predictors variable exists. The value of VIF for all independent variables is below the value of 10 except for EPS and BVPS, VIF above 10 is normally considered to be a problem [52]. As our model is using closely related measures of bank's performance which results in interaction between several regressors this kind of result is expected [12]. The variables that depicted high level of colinearity were not dropped from the model because these are important variables to investors as well as to banking industry.

\subsection{Regression Analysis}

Table 5(a) and Table 5(b) present regression summary statistics, the summary of results for nine set accounting variables used in the study is presented below: 
Table 4. Correlation matrix between variables.

\begin{tabular}{|c|c|c|c|c|c|c|c|c|c|c|}
\hline Variables & $M S P$ & $E P S$ & $B V P S$ & $R O E$ & $A T R$ & $C R$ & NIM & $C A R$ & $N P A$ & $C A S A$ \\
\hline \multicolumn{11}{|c|}{ Public sector banks } \\
\hline$M S P$ & 1 & $0.932^{* *}$ & $0.911^{\star}$ & 0.191 & $0.250^{*}$ & -0.023 & 0.192 & -0.049 & -0.132 & 0.108 \\
\hline EPS & & 1 & 0.964 & 0.235 & 0.321 & -0.043 & 0.202 & -0.028 & -0.115 & 0.076 \\
\hline$B V P S$ & & & 1 & 0.123 & 0.300 & -0.034 & 0.217 & -0.051 & -0.035 & 0.112 \\
\hline$R O E$ & & & & 1 & 0.037 & -0.053 & 0.346 & 0.215 & -0.658 & 0.046 \\
\hline$A T R$ & & & & & 1 & -0.037 & 0.049 & -0.089 & 0.049 & -0.099 \\
\hline$C R$ & & & & & & 1 & -0.077 & 0.333 & 0.095 & 0.193 \\
\hline$N I M$ & & & & & & & 1 & 0.040 & -0.116 & 0.536 \\
\hline$C A R$ & & & & & & & & 1 & -0.283 & 0.050 \\
\hline$N P A$ & & & & & & & & & 1 & 0.074 \\
\hline$C A S A$ & & & & & & & & & & 1 \\
\hline \multicolumn{11}{|c|}{ Private sector banks } \\
\hline$M S P$ & 1 & & & & & & & & & \\
\hline$E P S$ & $0.577^{* *}$ & 1 & & & & & & & & \\
\hline$B V P S$ & $0.631^{* *}$ & 0.956 & 1 & & & & & & & \\
\hline$R O E$ & 0.253 & 0.343 & 0.207 & 1 & & & & & & \\
\hline$A T R$ & 0.188 & -0.065 & -0.116 & 0.231 & 1 & & & & & \\
\hline$C R$ & 0.202 & -0.104 & -0.058 & 0.025 & 0.255 & 1 & & & & \\
\hline NIM & $0.445^{* *}$ & 0.238 & 0.174 & 0.391 & 0.408 & 0.244 & 1 & & & \\
\hline$C A R$ & 0.335 & 0.232 & 0.280 & 0.260 & 0.159 & 0.257 & 0.374 & 1 & & \\
\hline$N P A$ & -0.269 & -0.291 & -0.212 & -0.527 & -0.119 & -0.119 & 0.029 & -0.214 & 1 & \\
\hline$C A S A$ & $0.699^{* *}$ & 0.529 & 0.578 & 0.098 & -0.017 & -0.038 & 0.435 & 0.164 & -0.163 & 1 \\
\hline
\end{tabular}

Note: ${ }^{*}$ Significant at $p<0.01 ;{ }^{*}$ Significant at $p<0.05$.

\section{1) Earnings per Share:}

- Coefficient of EPS is positive and significant at $1 \%$ level for public sector banks. These results indicate that there is positive association between the performance of the business as measured by earnings per share and market share price.

- The regression coefficient of EPS in private sector banks is significant at $p<$ 0.10 and depicts a positive association with market share prices. The findings are in line with the findings of [13] [15] [53] [54] [55] [56].

\section{2) Book Value per Share}

- The beta coefficient of $B V P S$ is significant at $p<0.05$ and have positive coefficient. The value signifies that there is direct relationship between $B V P S$ and market share prices of public sector and this implies that a unit increase in $B V P S$ will leads to 0.348 increases in market share prices.

- In private sector banks, the coefficient of book value per share is also positive and significant. 
Table 5. (a) Regression results; (b) Regression model summary.

(a)

\begin{tabular}{|c|c|c|c|c|}
\hline Variable & Coefficient & Std. Error & t-statistic & Prob. \\
\hline \multicolumn{5}{|c|}{ Public Sector Banks (Random effect model) } \\
\hline $\mathrm{C}$ & 347.61 & 387.76 & 0.90 & 0.371 \\
\hline EPS & 7.480 & 0.86 & 8.66 & $0.000^{* * *}$ \\
\hline$B V P S$ & 0.348 & 0.17 & 2.03 & $0.043^{\star *}$ \\
\hline$R O E$ & 13.16 & 6.62 & 1.99 & $0.048^{\star *}$ \\
\hline$A T R$ & -183.99 & 311 & -0.59 & 0.555 \\
\hline$C R$ & 697.80 & 875.64 & -0.80 & 0.426 \\
\hline NIM & -16.81 & 64.20 & -0.26 & 0.794 \\
\hline$C A R$ & -25.98 & 25.12 & -1.03 & 0.302 \\
\hline$N P A$ & -150.95 & 42.23 & -3.57 & $0.000^{* * *}$ \\
\hline$C A S A$ & 9.88 & 6.45 & 1.53 & 0.127 \\
\hline \multicolumn{5}{|c|}{ Note: ${ }^{* *}$ Significant at $p<0.01 ;{ }^{*}$ Significant at $p<0.05 ;{ }^{\star}$ Significant at $p<0.10$} \\
\hline \multicolumn{5}{|c|}{ Private Sector Banks (Fixed effect model) } \\
\hline $\mathrm{C}$ & -119.20 & 220.10 & -0.54 & 0.59 \\
\hline EPS & 4.083 & 2.356 & 1.73 & $0.08^{*}$ \\
\hline$B V P S$ & 1.340 & 0.496 & 2.700 & $0.01^{*}$ \\
\hline$R O E$ & -0.372 & 2.77 & -0.13 & 0.89 \\
\hline$A T R$ & 2476.128 & 1340.91 & 1.84 & $0.07^{\star}$ \\
\hline$C R$ & 2286.175 & 1272.25 & 1.80 & $0.07^{*}$ \\
\hline NIM & 80.24 & 51.28 & 1.56 & 0.12 \\
\hline$C A R$ & -7.55 & 9.72 & -0.78 & 0.44 \\
\hline$N P A$ & -3.28 & 14.71 & -0.22 & 0.82 \\
\hline$C A S A$ & 3.00 & 4.05 & 0.74 & 0.46 \\
\hline
\end{tabular}

(b)

\begin{tabular}{ccc}
\hline & Public Sector Banks & Private Sector Banks \\
\hline $\mathrm{R}^{2}$ & 0.866 & 0.787 \\
Adj. $\mathrm{R}^{2}$ & 0.860 & 0.747 \\
F-Value & 157.60 & 19.62 \\
Significance & 0.000 & 0.000 \\
Hausman Test & 16.0910 & 38.7180 \\
& $(0.065)$ & $(0.000)^{\star * \star}$ \\
\hline
\end{tabular}

These results are consistent with the findings of [53] and are contrary to [50].

\section{3) Return on Equity}

The coefficient of $R O E$ in our study is positive but significant at $10 \%$ in public sector banks, which indicates that there is positive and significant relationship 
between $R O E$ and market share prices. The findings are consistent with the results of previous research [12] [39] [42].

For private sector banks, the regression coefficient of $R O E$ has been positive and statistically not significant, which indicates that $R O E$ is not statistically significant in explain market share price. The reason for the insignificance of return on equity could be that, perhaps most of investors depend on $B V P S$ and other accounting variables used in this study rather $R O E$. These results are consistent with the findings of [6].

\section{4) Assets Turnover Ratio}

Assets turnover ratio is insignificant in case of public sector banks. Our results are consistent with the findings of with [42].

For private sector banks, regression coefficient of $A T R$ is positive at significance of $p<0.10$ level, this indicates that $A T R$ is highly significant at $10 \%$ level in explaining market share price.

\section{5) Current Ratio}

For public sector banks, $C R$ reported as insignificant variable, the results are consistent with the findings of [10] [42].

In the study conducted by [44] current ratio reported as significant variable in influencing market share prices. The coefficient of $C R$ in our study is positive at significance of $p<0.10$ level in private sector.

\section{6) Net Interest Margin}

Net interest margin reported as insignificant which indicates that the NIM is not relevant factor in deciding market share price of private and public sector banks.

\section{7) Capital Adequacy Ratio}

The beta coefficient of capital adequacy ratio is insignificant and depicts a negative association with market share prices of private and public sector banks.

\section{8) Net Non-Performing Assets Ratio}

- For public sector banks, the coefficient of $N P A$ is negative at a significant of $p<0.05$ level. This indicates that at $5 \%$ level of significance $N P A$ is relevant in influencing market share price.

- Net non-performing assets ratio in this study found as insignificant variable in private sector banks. This implies that $N P A$ are not relevant in deciding market share prices.

\section{9) $C A S A$ Ratio}

$C A S A$ reported as insignificant variable in public and private sector banks.

Further, the estimated regression results also shows that for public sector banks, the value of adj. $R^{2}$ is 0.866 and indicates that accounting numbers explain about $86.6 \%$ of the variations in market share prices and this is greater than the adj. $R^{2}$ of 0.787 found in private sector banks. Given the respective value of adj. $R^{2}$ reported under both sectors, it is posit to note that the value relevance of accounting information in the public sector banks is more relevant than that of the private sector banks and this supports the hypothesis of the study that: there is significant difference in the value relevance of accounting information between 
public sector banks and private sector banks listed under BSE 500. Table 6 presents summary of all significant and insignificant variables

\section{Discussion and Concluding Remarks}

This study compared value relevance of accounting information on the market share price of Indian banks listed in BSE. In particular, it attempts to identify relevant accounting information in influencing market share price and see whether there is significance difference in the value relevance of accounting information between private and public sector banks. The study uses panel data regression methodology (FEM and REM) in testing the relationship accounting information and market share price of listed Indian banks for a period of 10 years.

The empirical results from the regression output provide evidence that EPS, $B V P S, R O E$ and Net $N P A$ ratio significantly influence market share price of public sector banks while $A T R, C R, N I M C A R$ and $C A S A$ were reported as insignificant variables in influencing market share price. Out of four accounting variable reported as significant variables in influencing market share price in public sector banks, EPS, BVPS and ROE positively and significantly influence market share price and Net $N P A$ ratios negatively influence market share price; the rest of accounting variables are not significant.

In private sector banks, EPS, BVPS, $A T R$ and $C R$ were reported as significant variables in influencing market share price and all these variables have positive association with stock prices. Other accounting variables like $R O E, N I M, C A R$, NetNPA and CASA in this study were found as insignificant variables in influencing market share price of private sector banks. Given the respective value of adj. $\mathrm{R}^{2}$ reported under both sectors in Table $5(\mathrm{~b})$, it is posit to note that accounting information in the public sector banks is more relevant than that of the private sector banks and this supports the hypothesis of the study that: there is significant difference in the value relevance of accounting information between public sector banks and private sector banks.

Table 6. Relationship between market share prices and accounting variables.

\begin{tabular}{ccc}
\hline Variable & Public Sector Banks (REM) & Private Sector Banks (FEM) \\
\hline EPS & Significant and Positive at 1\% & Significant and Positive at $10 \%$ \\
ROE & Significant and Positive at $5 \%$ & Significant and Positive at $10 \%$ \\
ATR & Significant and Positive at $10 \%$ & Not Significant \\
CR & Not Significant & Significant and Positive at $10 \%$ \\
$N I M$ & Not Significant & Significant and Positive at $10 \%$ \\
$C A R$ & Not Significant & Not Significant \\
$N P A$ & Not Significant & Not Significant \\
$C A S A$ & Significant and Negative at 1\% & Not Significant \\
\hline
\end{tabular}




\section{Limitation and Suggestions for Future Research}

Empirical findings of this study have important implication to Indian investors under banking sector and other users of financial statements and also subjected to several limitations. First, the study compared only value relevance of few selected accounting information from the balance sheet and income statement. Future researchers may add more variables relevant to banking sectors.

Second, the conclusions are based on the analysis of banking sector for the period 10 years from 2005-2014 for better generalization of results; the period covered can be extended to 15 years and other sectors like Oil and Gas, Manufacturing sectors, Service sectors and other non-financial sector should be considered.

Lastly, it will be more important and interesting to see more empirical comparative studies on the value relevance of accounting information between countries like in the study of [32] and [57].

\section{Conflicts of Interest}

The authors declare no conflicts of interest regarding the publication of this paper.

\section{References}

[1] Bhatia, M. (2018) Capital Market and Financial Statements. The Management Accountant Journal, Institute of Cost accountants of India, 53, 54-59.

[2] Ball, R. and Brown, P. (1968) An Empirical Evaluation of Accounting Income Numbers. Journal of Accounting Research, 6, 159-178. https://doi.org/10.2307/2490232

[3] Kothari, S.P. (2001) Capital Market Research in Accounting. Journal of Accounting and Economics, 31, 105-231. https://doi.org/10.1016/S0165-4101(01)00030-1

[4] Barth, M.E., Beaver, W. and Landsman, W. (2001) The Relevance of the Value Relevance Literature for Financial Accounting Standard Setter: Another View. Journal of Accounting and Economics, 31, 77-104. https://doi.org/10.1016/S0165-4101(01)00019-2

[5] Francis, J. and Schipper, K. (1999) Have Financial Statements Lost Their Relevance? Journal of Accounting Research, 37, 319-352. https://doi.org/10.2307/2491412

[6] Vijitha, P. and Nimalathasan B. (2014) Value Relevance of Accounting Information and Share Price: A Study of Listed Manufacturing Companies in Sri Lanka. Merit Research Journal of Business and Management, 2, 1-6.

[7] Vishnani, S. and Shah, K. (2008) Value Relevance of Published Financial Statements with Special Emphasis on Impact of Cash Flow Reporting. International Research Journal of Finance and Economics, 17, 84-90.

[8] Modi, S. and Pathak, B. (2014) A Study on Value Relevance of Accounting Information in Indian Stock Market: The Case of Auto Sector. The International Journal of Business \& Management, 166-180.

[9] Mulenga, M. and Bhatia, M. (2017) The Review of Literature on the Role of Earnings, Cash Flow and Accruals in Predicting Future Cash Flows. Accounting and Finance Research, 6, 59-70. https://doi.org/10.5430/afr.v6n2p59 
[10] Mohanty, P.K. (2012) Relevance of Accounting Numbers: An Empirical Analysis of the IT and Steel Sector. Journal of Arts, Humanities \& Management, 1, 18-30.

[11] Sharma, M. (2014) Value Relevance of Accounting Information: A Comparative Study of Public and Private Sector Companies in India. Asia Pacific Journal of Research, 1, 113-121.

[12] Sharma, A., Kumar, S. and Singh, R. (2012) Value Relevance of Financial Reporting and Its Impact on Stock Prices: Evidence from India. South Asian Journal of Management, 19, 60-77.

[13] Khanna, M. (2014) Value Relevance of Accounting Information: An Empirical Study of Selected Indian Firms. International Journal of Scientific and Research Publications, 4, 1-6.

[14] Varun, D. (2012) Role of Fundamental Variables in Explaining Stock Prices: Indian FMCG Sector Evidence. Journal of Arts, Science \& Commerce, 3, 56.

[15] Varun, D. (2014) Earnings Persistence and Stock Prices: Empirical Evidence from an Emerging Market. Journal of Financial Reporting and Accounting, 12, 117-134. https://doi.org/10.1108/JFRA-06-2013-0044

[16] Bhatia, M. and Mulenga, M (2019) Value Relevance of Accounting Information: A Review of Empirical Evidence across Continents. Jindal Journal of Business Research. https://doi.org/10.1177/2278682118823307

[17] Bhatia, M. and Mulenga, M. (2019) Value Relevance of Accounting Information: Comparative Study of Indian Public and Private Sector Banks. International Journal of Indian Culture and Business Management, 18, 12-33. https://doi.org/10.1504/IJICBM.2019.096922

[18] Mulenga, M. and Bhatia, M. (2018) Review of Accounting Variables Affecting Stock Price Movements. Amity Business Review, 19, 91-105.

[19] Mulenga, M. and Bhatia, M. Value Relevance of Reported Financials of NSE listed Companies. Afro-Asian Journal of Finance and Accounting, in press.

[20] Srinivasan, P. and Narasimhan, M.S. (2010) An Evaluation of Value Relevance of Consolidated Earnings and Cash Flow Reporting in India. Proceedings of the 2nd International Conference on Corporate Governance. https://doi.org/10.2139/ssrn.2125749

[21] Bhatia, M. and Mehrotra, V. (2016) Determinants of Intellectual Capital Disclosure: Evidence from Indian Banking Sector. South Asian Journal of Management, 23, 89-111.

[22] Ahluwalia, M.S. (2002) Economic Reforms in India since 1991: Has Gradualism Worked? Journal of Economic Perspectives, 16, 67-88. https://doi.org/10.1257/089533002760278721

[23] Khanna, M. and Kaushal, S. (2013) Growth of Banking Sector in India: A Collective Study of History and Its Operations. Asian Journal of Advanced Basic Sciences, 2, 36-45.

[24] Miller, M.H. and Modiglian, F. (1966) Some Estimates of the Cost of the Capital to the Electric Utility Industry, 1954-57. American Economic Review, 56, 333-391.

[25] Beaver, W. (1968) The Information Content of Annual Earnings Announcement. Journal of Accounting Research, 6, 67-92. https://doi.org/10.2307/2490070

[26] Amir, E., Harris, T.S. and Venuti, E.K. (1993) A Comparison of the Value-Relevance of U.S. versus Non-U.S. GAAP Accounting Measures Using form 20-F Reconciliations. Journal of Accounting Research, 31, 230-264. https://doi.org/10.2307/2491172

[27] Ohlson, J.A. (1995) Earnings, Book Values and Dividends in Security Valuation. 
Contemporary Accounting Research, 11, 661-688.

https://doi.org/10.1111/j.1911-3846.1995.tb00461.x

[28] Holthausen, R.W. and Watts, R.L. (2001) The Relevance of the Value-Relevance Literature for Financial Accounting Standard Setting. Journal of Accounting and Economics, 31, 3-75. https://doi.org/10.1016/S0165-4101(01)00029-5

[29] Dhaliwal, D., Subramanyam, K.R. and Trezevant, R. (1999) Is Comprehensive Income Superior to Net Income as a Measure of Firm Performance? Journal of Accounting \& Economic, 26, 43-67. https://doi.org/10.1016/S0165-4101(98)00033-0

[30] Harris, T.S., Lang, M. and Moller, H.P., (1994) The Value Relevance of German Accounting Measures: An Empirical Analysis. Journal of Accounting Research, 32, 187-209. https://doi.org/10.2307/2491281

[31] Venkatachalam, M. (1996) Value Relevance of Banks' Derivatives Disclosures. Journal of Accounting and Economics, 22, 327-355. https://doi.org/10.1016/S0165-4101(96)00433-8

[32] Hellstrom, K. (2006) The Value Relevance of Financial Accounting Information in a Transition Economy: The Case of the Czech Republic. European Accounting Review, 15, 325-349. https://doi.org/10.1080/09638180600916242

[33] Bartov, E., Goldberg, S.R. and Kim, M. (2005) Comparative Value Relevance among German, U.S. and International Accounting Standards: A German Stock Market Perspective. Journal of Accounting, Auditing \& Finance, 21, 95-119. https://doi.org/10.1177/0148558X0502000201

[34] Graham, R.C. and King, R.D. (2000) Accounting Practices and the Market Valuation of Accounting Numbers: Evidence from Indonesia, Korea, Malaysia, the Philippines, Taiwan and Thailand. The International Journal of Accounting, 35, 445-470. https://doi.org/10.1016/S0020-7063(00)00075-3

[35] Barth, M. (1994) Fair Value Accounting: Evidence from Investment Securities and the Market Valuation of Banks. The Accounting Review, 69, 1-25.

[36] Brewer, E. and Lee, C.F (1986) Time Aggregation, Specification, and Bank Stock Rates of Returns Determination. College of Commerce and Business Administration, University of Illinois at Urbana-Champaign, Chicago, IL.

[37] Barth, E.M., Willian, H.B. and Wayne, R.L. (1996) Value Relevance of Banks' Fair Value Disclosures under SFAS No. 107. The Accounting Review, 71, 513-537.

[38] Nelson, K. (1996) Fair Value Accounting for Commercial Banks: An Empirical Analysis of SFAS No. 107. The Accounting Review, 71, 161-182.

[39] Pathirawasam, C. (2010) Value Relevance of Accounting Information: Evidence from Sri-Lanka. International Journal of Research N Commerce \& Management, 1 , 13-20.

[40] Siyanbola, A.A. (2016) The Value Relevance of Earnings in the Return-Earnings Relation in the Nigerian Deposit Money Banks. Congent Business \& Management, 3, Article ID: 1210276. https://doi.org/10.1080/23311975.2016.1210276

[41] Sharma, D.S. (2011) Determinants of Equity Share Prices in India. Journal of Arts, Science \& Commerce, 2, 51-60.

[42] Malik, M.F. and Ali, B. (2013) Value Relevance of Accounting Information: Evidence from Fuel and Energy Sector of Pakistan. Journal of Basic Applied Science Research, 3, 884-891.

[43] Bhatia, M. and Dhamija, S. (2015) Voluntary Disclosure of Financial Ratios in India. South Asian Journal of Management, 22, 29-51.

[44] Alam, H.M., Ali, L., Rehman, C.A. and Akram, M. (2011) Impact of Working Capi- 
tal Management on Profitability and Market Valuation of Pakistani Firms. European Journal of Economics, Finance and Administrative Sciences, 32, 48-54.

[45] Tushar B.D. (2013) Net Interest Margin, Financial Crisis and Bank Behavior: Experience of Indian Banks. Department of Economic Policy and Research, RBI Working Paper Series, 1-28.

[46] Singh, A. (2013) Performance of Non-Performing Assets in Indian Commercial Banks. International Journal of Marketing, Financial Services \& Research Management, 2, 86-94.

[47] Varun, D. (2015) The Relative Predictive Ability of Earnings and Cash Flows. Management Research Review, 38, 367-380. https://doi.org/10.1108/MRR-06-2013-0156

[48] Akbar, A. (2014) Working Capital Management and Corporate Performance: Evidences from Textile Sector of China. European Academic Research, 2, 11440-11456.

[49] Hausman, J.A. (1978) Specification Tests in Econometrics. Econometrica, 46, 1251-1271. https://doi.org/10.2307/1913827

[50] Shehzad, K. and Ismail, A. (2014) Value Relevance of Accounting Information and Its Impact on Stock Prices: Case Study of Listed Banks at Karachi Stock Exchange. Journal of Economic Info, 3, 40-48.

[51] Worthington, A.C. and Tracey, W. (2001) The Usefulness of Economic Value-Added (EVA) and Its Components in the Australian Context. Accounting, Accountability and Performance, 7, 73-90. https://ssrn.com/abstract=2169809

[52] Gujarati, D.N. (1995) Basic Econometrics. 3rd Edition, McGraw-Hill Inc., New York.

[53] Ghosh, P.K. and Ghosh, S.K. (2015) Stock Price Adjustment to Corporate Accounting Disclosure: A Quantitative Study on Dhaka Stock Exchange (DSE), Bangladesh. International Journal of Accounting and Financial Reporting, 5, 122-132.

[54] Thompson, S. (2012) Stock Market Crisis and Value Relevance of Accounting Information: Impact on Quoted Cement Manufacturing Firms in Nigeria. International Journal of Research in Commerce \& Management, 3, 16-20.

[55] Olugbenga, A. and Oyerinde, A. (2014) The Relationship between Financial Accounting Information and Market Values of Quoted Firms in Nigeria. Global Journal of Contemporary Research in Accounting, Auditing and Business Ethics, 1, 22-39.

[56] Sharma, S. and Singh, B. (2006) Determinants of Equity Share Prices in Indian Corporate Sector: An Empirical Study. The ICFAI Journal of Applied Finance, 12, 21-38.

[57] Chen, V.Y.S. and Ho, Y.K. (2014) The Association between Earnings and Returns: A Comparative Study between the Chinese and U.S Stock Markets. China Accounting and Finance Review, 16, 1-17. 